\title{
Павло ПІРНИКОЗА
}

\section{РОАЬ ФІСКАМЬНОГО ІНСТИТУЩІЙНОГО СЕРЕДОВИЩА У ДЕТІНІЗАЩІї ЕКОНОМІКИ}

\begin{abstract}
Розглянуто теоретичну сутність детінізації економіки, досліджено поняття "інституція" та "інституційне середовище". Запропоновано авторське тлумачення фіскального інституційного середовища, охарактеризовано його складові та виокремлено функиії, які воно виконує. З'ясовано взаємозв'язок між якістю фіскальних інституцій та рівнем тіньової економіки в країні. За результатами дослідження узагальнено низку принципів, на основі яких має фрормуватися фіскальне інституційне середовище, яке сприяло б детінізації економічних відносин.
\end{abstract}

Ключові слова: тіньова економіка, детінізація економіки, інституції, інституційне середовище, фіскальні інституції, фіскальне інституційне середовище.

\section{Павел ПИРНЫКОЗА}

Роль фискальной институциональной среды в детенизации экономики

Рассмотрено теоретическую сущность детенизации экономики, исследованы понятия "институция" и "институциональная среда". Предложено авторское толкование фискальной институциональной среды, охарактеризованы ее составляющие и выделены функции, которые она выполняет. Выяснена взаимосвязь между качеством фискальных институций и уровнем теневой экономики в стране. По результатам исследования обобщены ряд принципов, на основе которых должна формироваться фискальная институциональная среда, которая бы способствовала детенизации экономических отношений.

Ключевые слова: теневая экономика, детенизация экономики, институции, институциональная среда, фрискальные институции, фрискальная институциональная среда.

\footnotetext{
Pavlo PIRNYKOZA

The role of fiscal institutional environment in the formation of the process of economy unshadowing

Introduction. Today, the problem of the fiscal crisis appears in almost every country in the world. The permanent budget deficit forces the central and local governments to look for additional sources of financial resources. In developing countries, where the high level of shadow economy is present, one of such sources could be the potential revenue from economy unshadowing, which could be reached by changing the fiscal institutions.

The purpose of the article is to study the influence of the fiscal institutional environment on the size of the shadow economy and the theoretically outline the ways to improve it in order to form the process of economy unshadowing.
}

(c) Павло Пірникоза, 2018 
Results. According to the results of the analysis, it was provided an author's interpretation of the fiscal institutional environment: "a set of official and unofficial fiscal institutions (a set of legal and moral-ethical norms, rules) that regulate and control the activity (behavior) of fiscal relations' participant in the relevant society". Also, it was highlighted the functions, which it performs. It was theoretically described the parameters, which characterize the fiscal institutional environment and their influence on the level of the shadow economy.

Conclusion. The analysis of economic literature shows that for developing countries, in particular Ukraine, the formation of a qualitative official fiscal institutional environment is indispensable condition for the economy unshadowing. In this case, under the quality it is necessary to understand the degree of satisfaction of the needs of economic entities, taking into account the diverse direction of their interests. For developing countries, improvement of the quality of official fiscal institutional environment can only be achieved by obtaining such parameters (characteristics): stability, liberalism in tax rates, simplicity in tax administration procedures, transparency and efficiency in the use of budget funds, tightening in the context of penalties.

Keywords: shadow economy, economy unshadowing, institutions, institutional environment, fiscal institutions, fiscal institutional environment.

JEL Classification: G20 017.

Постановка проблеми. Проблема фіскальної кризи сьогодні стосується майже кожної країни світу, дефіцит бюджетів змушує державні та місцеві уряди шукати нові джерела доходів. Для країн, що розвиваються, зокрема України, де рівень тіньової економіки $є$ значним, розширення податкової бази можливе за рахунок детінізації ВВП. Існування великої частки неформального сектору в економіці зумовлює значні податкові втрати, скорочення яких потенційно могло б ліквідувати існуючі бюджетні дефіцити. Оскільки тіньова діяльність є тією господарською діяльністю, яка здійснюється поза межами одріційних інституцій (тобто не відповідає законодавству), то це означає, що останні $є$ несприятливими для неї. В іншому випадку суб'єктам господарювання не було б сенсу ризикувати, працюючи всупереч законодавству. Основними чинниками, які сприяють поширенню тіньових процесів, окрім надмірного податкового навантаження, економісти вважають неякісні та несприятливі офіційні інституції. 3 цього випливає, що їх зміна має вплив на розмір тіньової економіки, це стосується і фіскальних інституцій.

Аналіз останніх досліджень і публікацій. Інституціоналізм як напрям економічної теорії з кожним роком здобуває все більше прихильників. Одним із його апологетів був Д. Норт, який у своїх роботах досліджував сутність інституцій та інституційну зміну [2]. Середовище, яке утворюється під впливом інституцій, аналізували у своїх працях Л. Девіс [L. Devis] [3] та O. Вільямсон [O. Williamson] [4]. Науковці К. Олівер [C. Oliver] [5], В. Попов [7] та Я. Корнаї [6] досліджували якість інституційного середовища та її зв'язок із поведінковими стратегіями суб'єктів господарювання.

Фіскальні інституції в США та їх вплив на економіку розглядали вчені Б. Найт [B. Knight] та E. Левінсоном [A. Levinson] [12]. У праці А. Крисоватого [13] висвітлена роль інституцій у фіскальному регулюванні вітчизняної економіки. Вплив інституційного середовища, зокрема й фіскального, на обсяги тіньової економіки досліджували такі 
зарубіжні науковці, як С. Аруоба [S. Aruoba] [9], С. Джонсон [S. Johnson], Д. Кауфманн [D. Kaufmann], П. Зойдо-Лобатон [P. ZoidoLobaton] [10], Дж. Елгін [C. Elgin], О. Озтуналі [O. Oztunali] [11], Е. де Сото [H. de Soto] [21], В. Танзі [V. Tanzi] [17], Б. Торглер [B. Torgler], Ф. Шнайдер [F. Schneider] [8] та ін.

Віддаючи належне існуючим напрацюванням та не применшуючи їх вагомості, вважаємо, що залишається нерозкритим питання щодо ролі фіскального інституційного середовища у формуванні процесу детінізації економіки.

Метою статті є дослідження впливу фіскального інституційного середовища на обсяги тіньової економіки та теоретичне окреслення шляхів його удосконалення з метою формування процесу детінізації економіки.

Виклад основного матеріалу дослідження. Потреба пошуку шляхів детінізації економіки зумовила актуальність досліджень, присвячених виявленню причин появи та розвитку тіньових процесів. У контексті цієї проблематики зарубіжні дослідники найчастіше діляться на дві групи. Перша з яких головною причиною існування тіньової економіки вважає надмірне податкове навантаження, особливо на фонд оплати праці. Друга - низьку якість інституційного середовища, зокрема надмірну бюрократію, недосконале законодавство, слабку судову систему тощо. Серед зарубіжних науковців, на нашу думку, найбільш успішними в напрямку пошуку чинників, які стимулюють поширення тіньових процесів, були F. Schneider, A. Buehn, C. Montenegro [1]. Вони систематизували результати своїх численних досліджень в одній праці й виокремили найбільш вагомі причини тіньової економіки та ранжували їх за значимістю: 1) надмірне податкове навантаження та навантаження із внесків соціального страхування описують близько 40\% всієї дисперсії тіньової економіки; 2) податкова мораль
- 23\%; 3) якість державних послуг та роботи державних установ - 12\%; 3) інтенсивність державного регулювання економічної діяльності - 8\%. Слід зазначити, що майже усі перелічені чинники можна розглядати як ті, що впливають на параметри (характеристики) інституційного середовища.

Окреслення ролі фіскального інституційного середовища у формуванні процесу детінізації економіки спочатку потребує чіткого визначення поняття "детінізація економіки". В одному з попередньо проведених нами досліджень було з'ясовано, що під поняттям "детінізація економіки" слід розуміти процес зниження рівня тіньової економіки, а під "політикою детінізації економіки" - державну політику, яка сприяє зниженню рівня тіньової економіки. Така політика спрямована на ліквідацію чинників, які зумовлюють існування тіньового сектору, та створення сприятливого інституційного середовища, у якому неформальна діяльність була б занадто ризиковою й неефективною.

Поняття "інституція" (від лат. institution звичай) було запозичене економістами 3 соціології. Нобелівський лауреат Д. Норт визначав інституції як: 1) набір офіційних (законів) правил, неофіційних (норми моралі) обмежень і механізмів їх примусового впровадження; 2) створені людиною обмежувальні рамки, що організовують стосунки між людьми [2, с. 11]. Незважаючи на велику кількість трактувань цієї категорії іншими вченими, саме визначення Д. Норта стало найбільш вживаним у наукових колах.

У рамках інституційної теорії всі інституції поділені на два види: офіційні та неофіційні. Д. Норт зазначає, що відмінність між цими видами інституцій визначається становищем у ієрархії правил, а не суттю. У сукупності вони утворюють неперервний ряд правил від традицій і звичок до законів. Нобелівський лауреат вважає, що неофіційні правила не піддаються чіткому визна- 
ченню й однозначним способам перевірки їхнього значення, вони ніким не придумані, проте їх дотримання вигідне кожному. Поширеною та відносно простою формою таких правил є звичаї і традиції, які щоденно координують поведінку людини. Якщо неофріційні правила Д. Норт не структурував, то офіційні розділив на політичні, економічні правила та контракти. До перших вчений загалом відносив правила, що визначають ієрархічну структуру держави, до других правила, що визначають права власності, до третіх - специфічні правила для конкретної угоди про обмін [2].

Під впливом сформованих у суспільстві офіційних і неофіційних правил гри генерується певне середовище, в якому перебуває та здійснює свою діяльність господарюючий суб'єкт. Л. Девіс під інституційним середовищем пропонує розглядати сукупність фундаментальних політичних, соціальних і базових правових норм, які регулюють економічну і політичну діяльність [3, с. 133]. О. Вільямсон вважав, що інституційне середовище - це правила гри, що визначають контекст, у якому відбувається економічна діяльність $[4$, с. 38$]$.

Значимість інституційного середовища визначається його функціями, серед яких інституціоналісти виокремлюють дві основні: 1) зниження невизначеності; 2) створення стійкого середовища для взаємодії економічних агентів і зниження трансакційних витрат. Окрім зазначених функцій, в літературі також трапляються й інші:

- функція обмеженого вибору - інституційне середовище впроваджує додаткові правила, які визначають поведінку економічного суб’єкта, підкріплені існуванням санкцій юридичного та соціального характеру;

- функція формування переваг - інституції - це не лише змушення до певної поведінки, вони є втіленням загальноприйнятих норм мислення та поведінки, тому впливають на фрормування переваг і цінностей індивіда;

- функція впливу на поведінку економічних суб'єктів - ефективність юридичних санкцій і неформальні правила поведінки мають значний вплив на тип поведінки суб'єктів господарювання, який коливається від опортунізму до "повної покори";

- функція впливу на структуру стимулів - встановлені правила стимулюють суб'єктів господарювання до ефективного використання ресурсів для максимізації прибутку;

- розподільча фуннцція - у кожному інституційному середовищі має місце свій розподіл політичної й економічної влади, оскільки розширення прав одних суб'єктів неможливе без звуження прав інших.

Зважаючи на те, що інституційне середовище переважно розглядається як сукупність правил і норм (інституцій), зарубіжні науковці досліджують зв'язок між ним та поведінковими стратегіями фірм. Так, в зарубіжних дослідженнях неодноразово було доведено, що стратегії поведінки компаній, які ефективно працюють в одному інституційному середовищі, в іншому стають неефективними. Зокрема, К. Олівер вказуе, що суб'єкти господарювання не дотримуються усіх правил чи поведінкових рамок, встановлених офіційними інституціями. Саме від якості останніх залежить, яку зі стратегій поведінки обиратиме фірма - стратегію опору чи дотримання, кожна з яких має свої недоліки та переваги. Стратегія опору $є$ основним джерелом розвитку тіньових економічних процесів [5, с. 173-174].

Науковці виокремлюють різні показники, які характеризують якість інституційного середовища. Найчастіше - трансакційні витрати. Зокрема, у працях Я. Корнаї це рівень довіри до національної економіки, ступінь якого можна виміряти різними способами, зокрема за допомогою підрахунку 
рівня передплат (в розвинених країнах він не перевищує 10\%, у пострадянських країнах - 40\%) [6]. В. Попов індикатором стану інституційного середовища розглядає рівень державних видатків. Підрив фрінансової потужності держави призводить до неефективності інституцій, що знижує економічну активність і ефективність накопичення [7]. На нашу думку, якісними є ті правила, які добровільно виконує переважна частина суспільства. Відтак, під якістю інституційного середовища пропонуємо розуміти рівень відповідності параметрів (характеристик) інституціонального середовища потребам й інтересам суб'єктів господарювання.

У зарубіжних наукових роботах досліджується вплив якості інституційного середовища на розміри тіньової економіки. Б. Торглер і Ф. Шнайдер [8] виявили негативний кореляційний зв'язок між різними показниками інституційної якості та рівнем тінізації економіки, зробили висновок, що покращення якості інституційного середовища дає змогу зменшити розміри неформального сектору. Висока якість інституційного середовища дає можливість кожному громадянину задовольняти особисті інтереси та брати участь у політичному процесі, що підвищує довіру до державних установ. Все це знижує інтерес до роботи в тіньовому секторі. Подібні результати отримав у своєму емпіричному дослідженні С. Аруоба [9]. Так, дані засвідчили про існування значного рівня негативної кореляції між якістю інституційного середовища та розмірами тіньової економіки. С. Джонсон і його колеги [10] вважають, що перехід суб' єктів господарювання в тіньовий сектор у пострадянських країнах $€$ результатом хижацького характеру публічної влади, яка не сприяє зміцненню інтитуції права власності. Також вони емпірично довели, що в країнах, що розвиваються, чим менше державного регулювання, тим менший рівень тіньової економіки. Натомість в розвинених країнах така тенденція не помічена.

Упродовж останнього десятиріччя особливої уваги серед науковців набуло дослідження фіскальних інституцій, зміну яких вчені розглядають як можливий засіб подолання перманентного бюджетного дефіциту. Так, науковці Дж. Елгін та О. Озтуналі досліджували залежність рівня тіньової економіки від якості фіскального інституційного середовища [11]. Базуючись на структурі наявних даних, вони проаналізували розміри тіньової економіки, використовуючи рівняння регресії:

$$
\begin{aligned}
& I S_{i, t}=\sigma_{0}+\sigma_{1} G D P_{i, t}+\sigma_{2} G D P_{i, t} * \operatorname{Inst}_{i, t}+\sum_{k=3}^{n} \mu_{k} X_{k_{i, t}}+ \\
& +\mu_{i}+\gamma_{t}+\varepsilon_{i, t},
\end{aligned}
$$

де $I S_{i ; t}$ - розмір тіньової економіки як відсоток від ВВП ( $i$ - країна, $t$ - рік); GDP - ВВП на душу населення; Inst - якість фіскального інституційного середовища, розрахунок якої базувався на основі інтеграції кількох індикаторів, одержаних 3 веб-сайту Світового банку; $X_{k_{i, t}}-$ інші контрольні змінні; $\mu_{i} \mathbf{i} \gamma_{t}$ - територіальні (залежно від держави) та часові фріксовані ефректи, відповідно; $\varepsilon_{i, t}$ - значення помилки.

Основним завданням науковців було встановити, як зміни у фіскальному інституційному середовищі впливатимуть на розмір тіньової економіки за умови незмінності ВВП. Результати показали, що коливання показника середовища на один пункт спричинюе до зростання/зменшення тіньової економіки на $12,43 \%$. Проте це усереднені дані. Панельний аналіз довів, що тіньова економіка є вразливішою до позитивних змін в країнах, що розвиваються, ніж в розвинутих економіках. Такі переконливі результати мотивують наше подальше дослідження ролі фіскального інституційного середовища та фіскальних інституцій, що його формують, в детінізації економіки України. 
У науковій літературі фіскальні інституції найчастіше визначають як правила та обмеження, які регулюють відносини в процесі наповнення дохідної частини бюджетів і використання бюджетних коштів. Зокрема Б. Найт і Е. Левінсон до фіскальних інституцій відносять традиційні податкові та видаткові обмеження, вимоги до збалансування бюджету, резервні фонди тощо [12]. Цікавими, на нашу думку, $є$ й погляди А. Крисоватого, який дає таке визначення інститутам фіскальної політики: "це - форми взаємовідносин держави, податкоплатників та громадян-виборців і, з одного боку, право держави встановлювати, законодавчо регламентувати, організовувати справляння податків та податкових платежів, розподіляти податкові надходження, а 3 iншого боку - право суб'єктів ринку на судовий захист від неправомірних податкових вилучень, можливість здійснення громадського контролю за фіском; форми взаємовідносин між державою - позичальником і власниками її боргових зобов'язань, право держави протягом обумовленого терміну розпоряджатися залученими шляхом запозичення коштами та право кредиторів вимагати своєчасного обслуговування і погашення боргу" [13, с. 176].

Отже, фріскальні інституції є основою мобілізації доходів, яка забезпечує їх подальшу трансформацію у видатки, що сприяють економічному зростанню. Якісні фіскальні інституції є невід'ємним атрибутом фінансової стійкості високорозвинених країн. Разом з тим, у вищенаведених визначеннях акцент робиться саме на формальних правилах, натомість до уваги не беруться неформальні звичаї та традиції, які мають місце при сплаті податків й використанні бюджетних коштів. Такі неофіційні правила тісно пов'язанні з податковою культурою та культурою державного управління. Вони не ізольовані від законодав- ства, а тісно переплітаюся з ним, утворюючи фіскальне інституційне середовище.

Дотримуючись такого підходу у поглядах на фіскальні інституції, ми вважаємо, що фіскальне інституційне середовище - це середовище, яке формується під впливом офіційно встановлених норм фіскального законодавства та неофіційних, усталених у суспільстві законів, правил поведінки, що регулюють і контролюють діяльність (поведінку) суб'єктів фіскальних правовідносин (рис. 1). Офіційною складовою фіскального інституційного середовища є фіскальне законодавство. Воно формуеться під впливом державної фіскальної політики. Неофіційна складова фіскального інституційного середовища - це неформалізовані традиції, норми та правила, які координують діяльність суб'єктів фіскальних відносин. Вони формуються під впливом національної культури, зокрема податкової культури.

Відповідно до наданого вище визначення вважаємо, що до функцій, які виконує фіскальне інституційне середовище, належать:

1) зниження невизначеності у діяльності суб'єктів фіскальних відносин;

2) зниження трансакційних витрат, пов'язаних зі сплатою податків і використанням бюджетних коштів;

3) функція впливу на поведінку суб'єктів фіскальних відносин;

4) функція розподілу прав та обов'язків між суб'єктами фіскальних відносин.

Представники Світового банку в проекті "Doing Business" щороку дають оцінку сприятливості офіційних інституцій, які регулюють підприємницьку діяльність. Оцінюючи податкові інституції, вони беруть до уваги такі базові показники: 1) кількість податків та зборів; 2) час, витрачений на сплату платежів за рік; 3) рівень оподаткування; 4) індекс процедур після подання звітності та сплати податків. Окрім індикаторів затрат часу на 


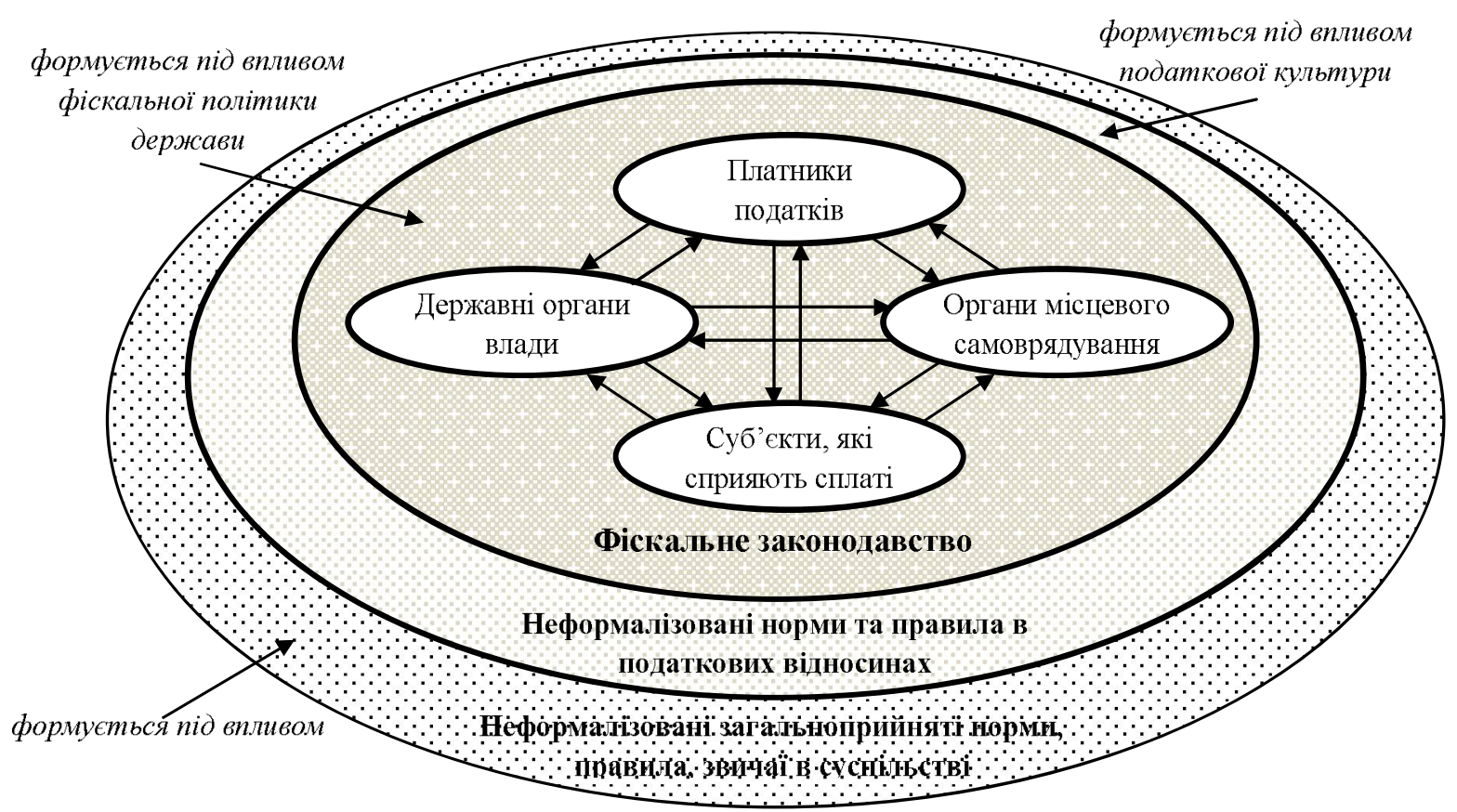

Рис. 1. Фіскальне інституційне середовище*

* Побудовано на основі теоретичних узагальнень фіскальної теорії.

нарахування та сплату податків, у 2017 р. вперше оцінювали процедури, що відбуваються після сплати податків (postfiling processes), a саме: 1) процедура бюджетного відшкодування ПДВ; 2) податкові перевірки; 3) адміністративне оскарження результатів податкових перевірок [14].

Рівень оподаткування в країні, як параметр, який характеризує фіскальне інституційне середовище, має неоднозначний вплив на рівень тіньової економіки. 3 теоретичної точки зору, співвідношення між рівнем податкової ставки та обсягом прихованого доходу $є$ одним із питань, які ще не були остаточно вирішені. Ця суперечка почалася у 1970-хрр. і продовжується досі, оскільки деякі теоретичні моделі, серед яких модель М. Аллінгема й А. Сандмо [15], передбачають, що зі збільшенням податкової ставки звітний дохід не зазнає значних змін. Тобто підвищення податкових ставок не має значного впливу на ухилення від сплати податків.

Такі висновки піддали значній критиці інші науковці, оскільки низка емпірич- них досліджень, серед яких вже згадане дослідження Ф. Шнайдера та його колег, засвідчили, що більш високі податкові ставки зазвичай стимулюють ухилення від сплати податків. Вплив податкової ставки на бажання податкоплатника сплачувати податки досліджував А. Лаффер. Згідно 3 концепцією видатного адепта теорії економічної пропозиції, підвищення ставок оподаткування до певного рівня сприяє зростанню доходів бюджету, оскільки не знищує стимулів до підприємницької активності. Якщо ж ставки перевищують межу (30\%), вони пригнічують ділову активність у суспільстві, що в подальшому призводить до зниження податкових доходів бюджету, внаслідок скорочення підприємницької діяльності, збільшення випадків ухилення від оподаткування та розширення обсягів тіньової економіки (рис. 2). Відповідно до цієї концепції зниження податкових ставок має призводити до негативних ефектів. Проте на практиці такі припущення часто спростовувалися. Прикладом цього можуть 


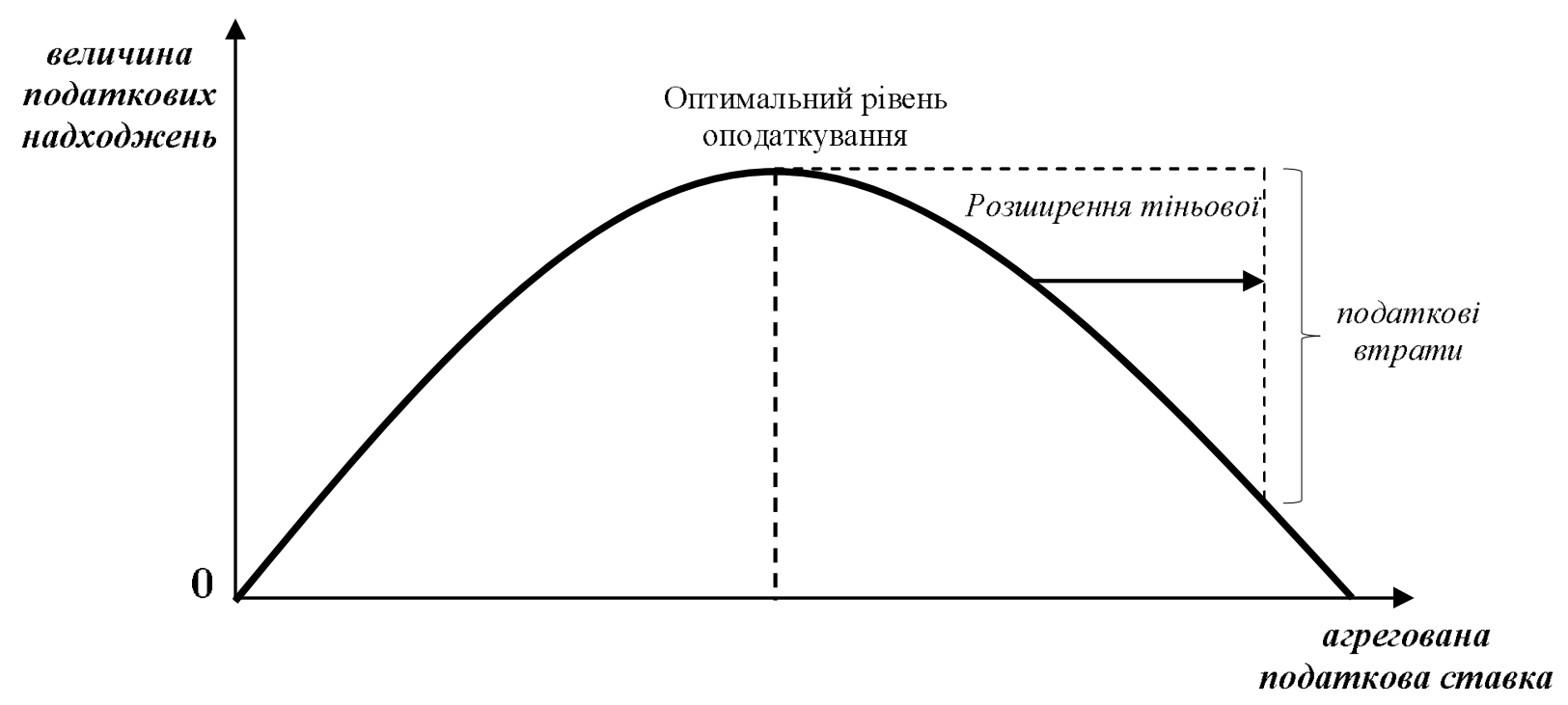

Рис. 2. Вплив рівня оподаткування на тіньову економіку згідно 3 концепцією А. Лафффера*

* Побудовано на основі теоретичних узагальнень фіскальної теорії.

бути невдалі податкові реформи Р. Рейгана в США у 1970-1980-х рр., які будувалися на основі ідей А. Лаффера.

На основі аналізу літератури можна зробити висновок, що хоча надмірний податковий тягар і є одним із найголовніших чинників, які стимулюють зростання обсягів тіньової діяльності, проте надмірність у цьому контексті $€$ відносною і залежить від інших чинників. Як показує практика, ефрективними можуть бути податкові системи як із високими ставками податків (країни Скандинавії), так і з незначним податковим тягарем (США). Зниження рівня оподаткування в країні, як інструмент до детінізації економіки, хоча й доцільне, проте не ефективне без забезпечення боротьби 3 корупцією, зміцнення правових інституцій та підвищення рівня ефективності використання бюджетних коштів.

Саме від якості створюваних державою суспільних благ залежить ставлення платника до існуючих податків та формування його позиції щодо роботи в офіційному чи тіньовому секторах. Ефективність відіграє ключове значення при використанні бюджетних ресурсів, оскільки дає можливість оцінити результати. Економічна ефективність, передусім, передбачає отримання максимально можливого результату від витрачених ресурсів. Підвищення ефективності витрачання бюджетних ресурсів потребує забезпечення відповідних інституційних умов. У цьому контексті варто зазначити, що сьогодні, найдієвішим інструментом забезпечення ефективності державних видатків вважається програмно-цільовий метод (ПЦМ) використання бюджетних коштів.

Підвищення ефективності використання бюджетних коштів нерозривно пов'язане із застосуванням принципу прозорості як важливого елементу системи якості управління державними фінансами. Кожен платник податків має знати, якими ресурсами володіє держава; скільки коштів надійшло до бюджету і яким чином вони використані; чи використовують сплачені податки на задоволення нагальних соціально-економічних проблем; наскільки ефективно використовуються бюджетні ресурси; що стало причиною неефективного використання і т. д. В іншому випадку податкоплатник не відчуватиме важливості й імперативнос- 
ті (обов'язковості) сплати податку. Як зазначив міністр фінансів Франції у 1792 р.: "Народ ніколи не відмовляеться платити розумні податки: розумні у їхньому використанні й розумно обтяжливі" [16, с. 53].

На бажання платника податків сплачувати "обов'язковий платіж" також має вплив те, як цей платіж стягують, тобто ефективність процедур у процесі адміністрування. Результати деяких досліджень $[17,18]$ свідчать, що неадекватні та слабкі податкові інституції є причиною розширення обсягів тіньової економіки. Якщо правові основи та правозастосування в країні $є$ неякісними і нестабільними, то мотивація та можливість ухилення від оподаткування зростатимуть. Підвищення ефективності податкового адміністрування не означає збільшення кількості податкових регулятивних норм, оскільки існує ризик того, що посилення регулювання робить податкову систему складнішою та підвищує силу бюрократії. Зокрема в країнах $з$ перехідною економікою, яким притаманні слабкі політичні й економічні інституції, розширення повноважень державних органів часто призводить до утисків бізнесу, зростання рівня корупції, переходу підприємців у тіньовий сектор.

На думку представників Міжнародного валютного фонду, державам, які мають намір сприяти процесу детінізації економіки, слід сфокусуватися на: 1) спрощенні податкового законодавства та процедур адміністрування податків; 2) зниженні податкових ставок для мікро- та малого бізнесу; 3) зниженні бар'єрів для входу в офіційний сектор економіки; 4) сприянні більш гнучкому процесу найму та звільнення працівників; 5) покращенні та розширенні соціальних програм і програм охорони здоров'я [19, с. 4].

Ще одним чинником, який впливає на бажання суб'єкта господарювання функціонувати в офріційному секторі, є стабільність формальних фіскальних інституцій. Ми по- годжуємося з С.Г. Пепеляєвим, що: "Платник податків має точно знати не лише умови справляння того чи іншого податку, а й бути впевненим у тому, що ці умови залишаються незмінними протягом певного періоду. Глобальна невизначеність виховує недовіру до держави і є серйозною перешкодою розвитку виробництва та підвищення добробуту громадян" [20, с. 18]. Відсутність стабільності в будь-якій системі виводить її з рівноваги та заважає належному функціонуванню. Постійна мінливість "правил гри" для платників податків робить державу ненадійним партнером, створюючи тим самим передумови для переходу в тіньовий сектор.

Нестабільність офріційних податкових інституцій в країнах із перехідною економікою часто пов'язана з різкими змінами в фіскальній політиці уряду, які продиктовані то потребою бюджету в додаткових фінансових ресурсах, то бажанням політиків перед виборами сподобатися платникам податків. Ефективним інструментом обмеження фіскальної політики $€$ застосування фріскальних правил, які все частіше розглядають як невід'ємний елемент дизайну механізму макроекономічної політики, зорієнтованої на прозорість і довгострокову ефективність. Фіскальні правила обмежують фіскальну політику держави шляхом встановлення кількісних лімітів на бюджетні агрегати. Вони встановлюють рамки для фіскальної політики, які забезпечують її стабільність, що сприяе макроекономічній стабільності можливості проведення фіскальної консолідації. Це дає змогу суб'єктам господарювання вибудовувати стратегію у своїй діяльності, відновлює їх довіру до публічної влади, знижує бажання працювати в тіньовому секторі.

Негативний кореляційний зв'язок між якістю офіційного фіскального інституційного середовища та часткою тіньового сектору в економіці країни наочно проілюстровано на рис. 3. 


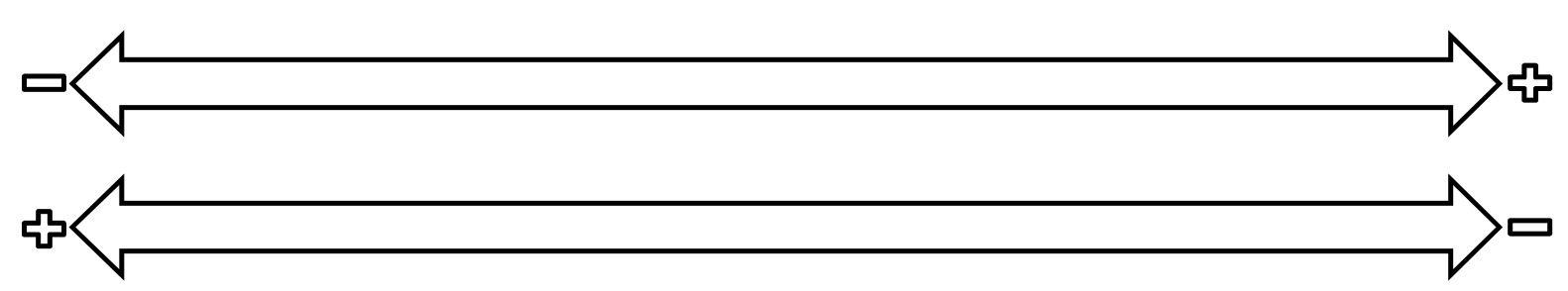

Рис. 3. Зв'язок якості офіційного інституційного середовища та обсягів тіньової економіки*

* Побудовано на основі теоретичних узагальнень фіскальної теорії.

Науковці зауважують, що сьогодні законодавство в країнах пострадянського простору і фіскальне законодавство, зокрема, підмінено системою неформальних інститутів, які регулюють специффічні трансакції, пов'язані зі сплатою податків і використанням бюджетних коштів. Фактично йдеться про неякісне офріційне інституціональне середовище, в умовах якого більшість учасників фіскальних відносин вважають за краще не виконувати закони, а слідувати неформальним правилам поведінки, оскільки це дає змогу максимізувати власні вигоди.

Якість офіційних інституцій ретельно досліджує Е. де Сото, який зазначає, що у країнах, які розвиваються, реформатори намагаються детінізувати економіку шляхом імпортування кращих, як їм здається, зразків законодавства. Але проблема, вважає Е. де Сото, в тому, що розвинені країни - експортери цих правових моделей - презентуючи своє законодавство як зразок для інших, вже забули про нюанси його становлення. Свій стрибок вони зробили зовсім не тому, що їх урядам вдалося якимось чином "витягти" тіньові практики в рамки хороших законів, вигаданих освіченими юристами. Навпаки - діючі в тіньовій економіці правила стали законами [47]. Тому варто зробити висновок, що копіювання офіційних фіскальних інституцій не є ефективним шляхом до детінізації економіки, оскільки державні закони мають відповідати орієнтирам відповідного суспільства й схвалюватися переважною його більшістю.
Висновки. За результатами дослідження можна зробити висновки, що фріскальне інституційне середовище - це середовище, яке формується під впливом офіційно встановлених норм фіскального законодавства та неофіційних, усталених у суспільстві законів, правил поведінки, що регулюють і контролюють діяльність (поведінку) суб'єктів фіскальних правовідносин. Воно виконує низку функцій, серед яких: зниження невизначеності у діяльності суб'єктів фріскальних відносин; зниження трансакційних витрат, пов'язаних зі сплатою податків і використанням бюджетних коштів; функція впливу на поведінку суб'єктів фіскальних відносин; функція розподілу прав та обов'язків між суб'єктами фіскальних відносин.

3'ясовано, що для країн, які розвиваються, зокрема для України, формування якісного офіційного фіскального інституційного середовища є невід'ємною умовою детінізації економіки. Під якістю пропонуємо розуміти ступінь задоволення потреб суб'єктів господарювання 3 урахуванням різнонаправленості їх інтересів. Наявність корупційної складової в фіскальних органах, що притаманно для цієї групи країн, зумовлює потребу у лібералізації законодавства, оскільки при високій інтенсивності регулювання господарської діяльності з боку держави для суб'єктів господарювання вигідніше функціонувати в тіньовому секторі, використовуючи неформальні зв'язки 3 працівниками контролюючих органів. Для підвищення якості фіскально- 
го інституційного середовища вважаємо об'єктивно необхідним формування його за такими принципами: стабільність; простота в адмініструванні податкових платежів; ліберальність у податкових ставках; прозорість та ефективність у використанні бюджетних коштів; жорсткість у контексті штрафних санкцій.

Разом з тим, забезпечення стабільного та ліберального податкового законодавства не відразу сприятиме значному рівню детінізації економіки, оскільки інституційна зміна пов'язана не лише зі зміною офіційних норм, а й неофіційних правил. Важливо здійснити масштабну державну кампанію щодо підвищення податкової культури суб'єктів господарювання як складової загальної культури нації. Така кампанія має бути наповнена прикладами прозорого й ефективного використання бюджетних коштів і прикладами боротьби з корупцією у вищих ешелонах влади. Без зміни ціннісних орієнтирів суспільства (неофіційних інституцій) неможливо досягти дотримання громадянами законодавства. Неофіційні правила поведінки мають базуватися на вірі у верховенство права та невідворотності настання покарання для кожного правопорушника. Це сприятиме формуванню нових неофіційних поведінкових імперативів та механізму їх примусового впровадження.

\section{Список використаних джерел}

1. Schneider $F$. Shadow economies all over the world: New estimates for 162 countries from 1999 to 2007 [Electronic resource] / F. Schneider, A. Buehn, C. Montenegro. The World Bank // Policy Research Working Paper. - 2010. - № 5356. Access mode : http://www.gfintegrity.org/storage/ gfip/documents/reports/world_bank_shadow_ economies_all_over_the_world.pdf

2. Норт Д. Інституиії, інституційна зміна та фрункціонування економіки / Д. Норт ; пер. 3 англ. І. Дзюби. - К. : Основи, 2000. - 198 с.
3. Davis L. Institutional change and American Economic Growth: A first step towards a theory of institutional innovation / L. Davis, D. North // The journal of economic history. - 1970. - Vol. 30. № 1. - P. 131-149.

4. Уильямсон О. Экономические институты капитализма: рынки, фирмы, "отношенческая" контрактация / О. Уильямсон. - СПб. : Лениздат, 1996. - $702 \mathrm{c}$.

5. Oliver $C$. Strategic responses to institutional processes / $C$. Oliver // The academy of management review. - 1991. - Vol. 16. - №1. P. 145-179.

6. Корнаи Я. Честность и доверие в переходной экономике / Я. Корнаи // Вопросы экономики. - 2003. - № 9. - С. 4-17.

7. Попов В. Сильные институты важнее скорости ресрорм / В. Попов // Вопросы економики. - 1998. - №8. - С. 56-70.

8. Torgler $B$. The impact of tax morale and institutional quality on the shadow economy [Electronic resource] / B. Torgler, F. Schneider. - IZA Discussion Paper No.2541 and CESifo Working paper series. - 2007. - N. 1899. - Access mode : https://papers.ssm.com/sol3/papers.cfm?abstract_ $i d=958248$

9. Aruoba S.B. Informal sector, Government Policy and institutions [Electronic resource] / S.B. Aruoba. - Access mode : http://www.eiefit/ files/2010/04/s-boragan-aruoba.pdf

10. Johnson S. Regulatory discretion and the unofficial economy / S. Johnson, D. Kaufmann, P. Zoido-Lobaton // American economic review. 1998. - Vol. 88 (2). - P. 387-92.

11. Elgin C. Institutions, informal economy and economic development [Electronic resource] / C. Elgin, O. Oztunali. - Working Papers 2013/03, Bogazici University, Department of Economics. 2013. - Access mode : http://www.econ.boun.edu. tr/content/wp/EC2013_03.pdf

12. Knight B. Fiscal institutions in U.S. [Electronic resource] / B. Knight, A. Levinson. - Working paper - 1998. - Access mode : http://faculty. georgetown.edu/am/6/pdfs\&zips/survey6.pdf 
13. Крисоватий А.І. Сочіально-ринкові інститути фоскальної політики / А.І. Крисоватий // Економіка і реаіон. - 2011. - № 30. C. $175-180$.

14. Doing business 2017: Equal opportunity for all [Electronic resource] / The World Bank Group Flagship Report. - Access mode : http://www. doingbusiness.org/ /media/WBG/DoingBusiness/Documents/Annual-Reports/English/DB17-Report.pdf

15. Allingham M. Income tax evasion: $A$ theoretical analysis / $M$. Allingham, A. Sandmo // Journal of public economics. - 1972. - Vol. 1 (3-4). P. 323-338.

16. Крисоватий А.І. Фінансові школи та логос теорії оподаткування / A.I. Крисоватий // Світ фінансів. - 2005. - Вип. 3-4 (4-5). C. 53-68.

17. Tanzi V. Fiscal reform over ten years of transition [Electronic resource] / V. Tanzi, G. Tsibouris. - IMF Working Paper WP/00/113. - 2000. Access mode : https://www.imf.org/external/pubs/ft/ wp/2000/wp00113.pdf

18. Johnson S. Institutions and the underground economy [Electronic resource] / S. Johnson, D. Kaufmann // $A$ decade of transition: achievements and challenges; edited by O. Havrylyshyn and S. M. Nsouli. - 2001. - Access mode: http://www.imf.org/en/Publications/Seminar-Volumes/Issues/2016/12/30/A-Decade-of-TransitionAchievements-and-Challenges-4058

19. Russell B. Revenue administration: managing the shadow economy [Electronic resource] / B. Russell. - Technical notes and manuals of fiscal affairs department of IMF. -2010 - - Access mode : https://hww.imf.org/external/ pubs/ft/tnm/2010/ tnm1014.pdf

20. Пепеляев С.Г. Основы налогового права : учеб. пособие / С.Г. Пепеляев. - М. : ФБКПPECC, 2000. $-343 \mathrm{c}$.

21. Сото де Э. Загадка капитала. Почему капитализм торжествует на Западе и терпит поражение во всем остальном мире [Electronic resource] / Э. de Como. - Access mode : https:// www.e-reading. club/book.php?book $=137496$.

\section{References}

1. Schneider, F., Buehn, A., Montenegro, C. (2010). Shadow economies all over the world: New estimates for 162 countries from 1999 to 2007. The World Bank. Policy Research Working Paper, 5356. Available at: http://www.gfintegrity.org/storage/gfip/ documents/reports/world_bank_shadow_economies_all_over_the_world.pdf

2. Nort, D. (2000). Instytutsii, instytutsiina zmina ta funktsionuvannia ekonomiky [Institutions, institutional change and functioning of the economy]. (Trans. I. Dziuba). Kyiv: Osnovy, 2000 [in Ukrainian].

3. Davis, L., North, D. (1970). Institutional change and American Economic Growth: $A$ first step towards a theory of institutional innovation. The journal of economic history, 1, 131-149 (Vol. 30).

4. Uilyamson, O. (1996). Ekonomicheskie institutyi kapitalizma: ryinki, firmyi, "otnoshencheskaya" kontraktatsiya [Economic institutions of capitalism: markets, firms, "relative" contracting]. SPb.: Lenizdat [in Russian].

5. Oliver, C. (1991). Strategic responses to institutional processes. The academy of management review, 1, 145-179 (Vol. 16).

6. Kornai, Ya. (2003). Chestnost $i$ doverie $v$ perehodnoy ekonomike [Honesty and trust in the transitional economy]. Voprosyi ekonomiki-Issues of economics, 9, 4-17 [in Russian].

7. Popov, V. (1998). Silnyie institutyi vazhnee skorosti reform [Strong institutions are more important than the speed ofreforms]. VoprosyiekonomikiIssues of economics, 8, 56-70 [in Russian].

8. Torgler, B., Schneider, F. (2007). The impact of tax morale and institutional quality on the shadow economy. IZA Discussion Paper, 2541 and CESifo Working paper series, 1899. Available at: https://papers.ssrn.com/so/3/papers.cfm?abstract_ id $=958248$

9. Aruoba, S.B. Informal sector, Government policy and institutions. Available at: http://www.eief. it/files/2010/04/s-boragan-aruoba.pdf

10. Johnson, S., Kaufmann, D., Zoido-Lobaton, $P$. (1998). Regulatory discretion and the unof- 
ficial economy. American economic review, 88 (2), $387-392$.

11. Elgin, C., Oztunali, O. (2013). Institutions, informal economy and economic development. Working Papers 2013/03, Bogazici University, Department of Economics. Available at: http://Www. econ.boun.edu.tr/content/wp/EC2013_03.pdf

12. Knight, B., Levinson, A. (1998). Fiscal institutions in U.S. States. Working Paper. Available at: http://faculty.georgetown.edu/am/6/pdfs\&zips/ survey6.pdf

13. Krysovatyi, A.I. (2011). Sotsialno-rynkovi instytuty fiskalnoi polityky [Social-market institutions of fiscal policy]. Ekonomika i rehion - Economy and region, 30, 175-180 [in Ukrainian].

14. Doing business 2017: Equal opportunity for all. The World Bank Group Flagship Report. Available at: http://www.doingbusiness.org/ /media/ WBG/DoingBusiness/Documents/Annual-Reports/ English/DB17-Report.pdf

15. Allingham, M., Sandmo, A. (1972). Income tax evasion: $A$ theoretical analysis. Journal of public economics, 1 (3-4), 323-338.

16. Krysovatyi, A.I. (2005). Finansovi shkoly ta lohos teorii opodatkuvannia Financial schools and the logos of the theory of taxation. Svit finansiv Finance of world, 3-4 (4-5), 53-68 [in Ukrainian].

17. Tanzi, V., Tsibouris, G. (2000). Fiscal reform over ten years of transition. IMF Working Paper WP/00/113. Available at: https://www.imf.org/ external/pubs/ft/wp/2000/wp00113.pdf
18. Havrylyshyn, O. (Eds.), Johnson, S., Kaufmann D. (2001). Institutions and the underground economy. A decade of transition: achievements and challenges. Available at: http:// www.imf.org/en/Publications/Seminar-Volumes/ Issues/2016/12/30/A-Decade-of-TransitionAchievements-and-Challenges-4058

19. Russell, B. (2010). Revenue administration: managing the shadow economy. Technical Notes and Manuals of Fiscal Affairs Department of IMF. Available at: https://www.imf.org/external/ pubs/ft/tnm/2010/tnm1014.pdf

20. Pepelyaev, S.G. (2000). Osnovyi nalogovogo prava [Basics of tax law]. Moscow: FBKPRESS [in Russian].

21. Soto de E. Zagadka kapitala. Pochemu kapitalizm torzhestvuet na Zapade i terpit porazhenie vo vsem ostalnom mire [Riddle of capital. Why capitalism triumphs in the West and is defeated in the rest of the world]. Available at: https:/Www.ereading. club/book. php? book $=137496$

Стаття надійшла до редакції 14.12.2017. 